\title{
Comprehensive Revelation on the Tomb Towers Architecture; Persia and Anatolia
}

\author{
Zeynab Nazer ${ }^{\circledR}$, Gergő Máté Kovács ${ }^{2}{ }^{\odot}$, Péter Rabb ${ }^{3 \odot}$ \\ ${ }^{1}$ PhD student, Faculty of Architecture, Department of History of Architecture and Monument Preservation, Pál Csonka Doctoral \\ School, Budapest University of Technology and Economics, Budapest, Hungary. (Principal contact for editorial \\ correspondence), Email: nazer.znb@gmail.com \\ 2 PhD student, Faculty of Architecture, Department of History of Architecture and Monument Preservation, Pál Csonka \\ Doctoral School, Budapest University of Technology and Economics, Budapest, Hungary. Email: gergomatekovacs@gmail.com \\ ${ }^{3}$ Asst. Prof. Dr., Faculty of Architecture, Department of History of Architecture and Monument Preservation, Pál Csonka \\ Doctoral School, Budapest University of Technology and Economics, Budapest, Hungary. Email: rabb@eptort.bme.hu
}

\begin{abstract}
Purpose

This article articulates the origin and development of early Islamic tomb tower architecture to middle period and evaluates similarities between Seljuq tomb tower architecture in Persia and Anatolia. To better understanding of the architectural history of this period, it is necessary to specify the description of the general features and its formation. The aim of this article was to suggest a methodological way, which algorithmically described, how the heritage of Persian Pre-Islamic architecture evolved and how the basic principles of Persian Early Islamic tomb tower architecture were developed. Consequently, the aim was to describe the influence on the Anatolian tomb tower architecture in an objective way, and to categorize the elemental features.
\end{abstract}

\section{Design/Methodology/Approach}

First, the article identifies the original traits of the Seljuq Empire mausolea i.e. domed cube and tomb tower, and their influence on Anatolian architecture. In addition, the morphological features, and typological structure propose an objective approach for the comparison of Persian and Anatolian mausoleum architecture in the Middle Period of the Early Islamic Era (10 to 12 AD).

Subsequently, the morphological and structural similarities and differences in the architecture of these two territories have been examined along with their use and development in the historical process.

\section{Findings}

As a result, this can prove the hypothesis that the main architectural features have not changed radically, and the basis has remained similar. However, the decorations can be changed rapidly in a more variable way. The research also points, almost all the possible spatial and structural variations have been manifested amongst the early mausolea with a wide range of variations and combinations. Despite the similarities in the polygon of the plan, there are more differences in the construction and shape of domes.

\section{Research Limitations/Implications}

the inability to generalize the research findings.

Social/Practical Implications

Destruction of some of the case studies.

Originality/Value

The quantitative methodology used for better understanding the comparison result of the qualitative research.

Keywords: Early Islamic architecture, mausoleum architecture, Seljuq Empire, shrine, tomb towers 


\section{INTRODUCTION}

The early Islamic architecture of Iran was destroyed almost all together due to the Mongolian attack. Although a lot of the memories of the Turkish Seljuq architecture have remained owing to the more resistant building material (stones) and the smaller Mongolian attack.

The early ottoman architecture of tombs has created its style partly based on these traditions, and partly because of the effect of the Byzantine architecture. Its style must have been affected by the direct Persian impulses. This research marks out the exploration of this architectural network as a goal.

\section{AIM AND METHODOLOGY}

The aim of the research is to chart different aspects of the similarities and differences of the Persian and Anatolian Seljuq mausoleum architecture. First, the historical background will be analysed. Second, the most important key buildings will be listed, which are the archetypes or the most characteristic examples of the architectural group. Then, the specific features of these archetypical examples will be defined and classified as the main structural and spatial components. Finally, these features will be summarized and represented in matrices (figure 1). Therefore, the aim is to define a system, which can offer objective contribution to the architectural analysis of the connections in the Persian and Anatolian Seljuq mausoleum architecture.

The main objective is to define the basic elements of the two building groups and evaluate their similarities and differences in an objective way. Also, to describe, if there are any elements which are more frequent than the average.

Here, to study such an effect, some examples of the single chamber tomb tower (central tomb tower for individual burial) have been considered. The common historical background is the contribution of the Seljuqs, therefore in the analysis, the mausolea which were constructed in the Seljuq period of Anatolia and Persia were selected and analysed.

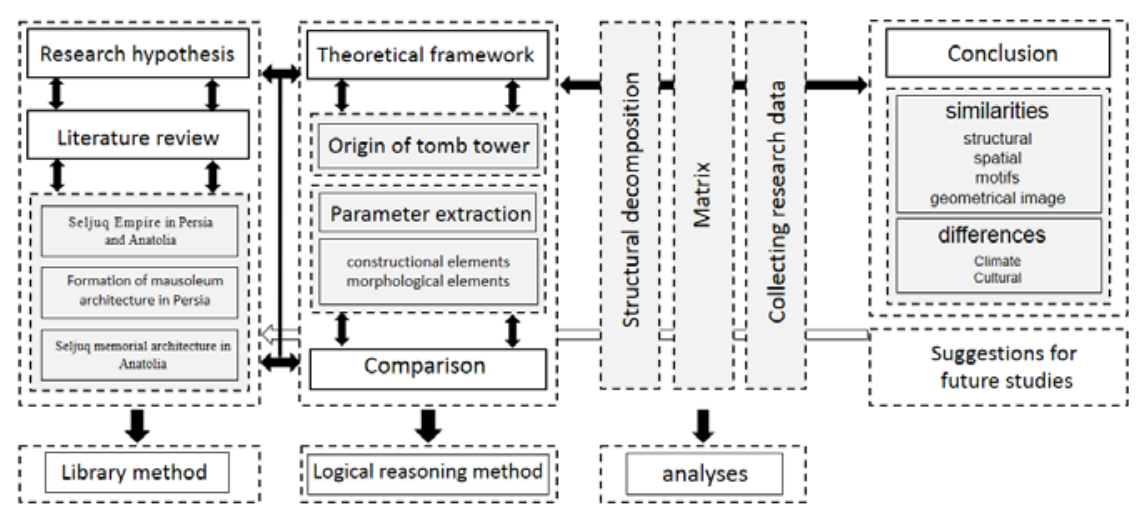

\section{THEORETICAL FOUNDATIONS}

In order to investigate the common features of the mausolea in Persia and Anatolia, it is necessary to examine the historical background of the
Figure 1. General structure and research Methodology (Authors). 
building type's development as well as the political and social conditions of the concerned territories during Seljuq Era (306 BC- cca. 150 BC). Therefore, the origins of the architectural similarities can be studied more properly.

\section{Historical Background of the Development of Early Islamic Mausoleum Architecture}

Since the Islamic influence covered a large area inhabited by heterogeneous population with different historical backgrounds, in the architecture of the concerned land the survival and continuousness of certain local, pre-Islamic customs remained to exist even in the Islamic era. One of the most typical manifestations of this phenomenon can be observed in the history of the architecture of mausolea. The shrines and tombs have appeared in unique architectural forms in all areas conquered by Islam.

Table 1. Historical background of the development of early Islamic mausoleum architecture in the Islamic era.

\begin{tabular}{|c|c|}
\hline $\begin{array}{l}\text { Northern } \\
\text { Africa } \\
\text { especially in } \\
\text { Egypt }\end{array}$ & $\begin{array}{l}\text { The different cults related to the deaths have played an important } \\
\text { role before the influence of the Islam. The direct and unique } \\
\text { relationship with the 'afterlife' did not disappear with the conquest } \\
\text { of Islam, either during the Fatimid dynasty (9th-12th centuries CE) } \\
\text { or during the pre-Ottoman Mamluk era (13th-16th centuries CE). } \\
\text { Therefore, it is not surprising that a significant part of Egypt's } \\
\text { architectural heritage consists of whole districts of necropolises (e.g. } \\
\text { Bab an-Nașr, the Eastern Necropolis and the Southern Necropolis or } \\
\text { Qaräfa of Cairo) which are even part of the everyday living space. }\end{array}$ \\
\hline Maghreb & $\begin{array}{l}\text { Both the shrines of holy people (marabout) both royal necropolises } \\
\text { can be observed - see the case of Shâlla in Morocco and Tlemcen in } \\
\text { Algeria- forming a unique manifestation of the memorial and funeral } \\
\text { architectural culture. (Nagy, 2018). However, the holy shrines have a } \\
\text { general, important role in urban formation as the targets from } \\
\text { pilgrimage, therefore, in many times, they are visited by crowded } \\
\text { amount of people. (Maroufi \& Rosina, p. 2017). }\end{array}$ \\
\hline $\begin{array}{l}\text { Eastern } \\
\text { Mediterranean } \\
\text { region }\end{array}$ & $\begin{array}{l}\text { Various, specific space structure of shrines can be observed. } \\
\text { According to K.A.C. Creswell's view, canopy tombs in Syria, } \\
\text { Palestine, and the Trans-Jordan region (e.g. Assar, Syria, } 3^{\text {rd }} \text { century } \\
\text { AD) have Egyptian roots (Saba Banat, Fustat, around 1010) and they } \\
\text { were created by circumventing the early Islamic tomb prohibition } \\
\text { by a less marked, essentially open, but covered structure, which "is } \\
\text { blown by the wind and where the sun shines." (Creswell, 1952). }\end{array}$ \\
\hline Central Asia & $\begin{array}{l}\text { A funerary architecture developed under the rule of the Samanids (r. } \\
\text { 819-999), a dynasty whose mausoleum is in Bukhara (today in } \\
\text { Uzbekistan), built in 907. The building has cubic structure with } \\
\text { brick decoration on all internal and external surfaces. The Great } \\
\text { Seljuq dynasty transferred this proclivity towards the construction } \\
\text { of monumental mausoleum in their expansion from Central Asia } \\
\text { into Mesopotamia and Anatolia. The mausoleum of Seljuq Sultan } \\
\text { Sanjar in Merv (c. 1157-1160), is one of the most impressive } \\
\text { examples of funerary architecture from that period, even though } \\
\text { today largely exist in ruins. }\end{array}$ \\
\hline
\end{tabular}

In the process of progressive expansion of Islam to the east following the Battle of Talas in 751, Islamic rule in the Central Asian region between Amu Darya and Syr Darya, or Transoxiana, was consolidated. Thus, the influence of the Muslim caliph of Baghdad became dominant in the 
former western Turkic territory. In parallel, a Persian ruler, the Samanids, represented the Baghdad Caliphate as an emirate at their headquarters in Samarkand and then in Bukhara. All these were reflected in the buildings: in the river basin, the influence of Pre-Islamic Persian architecture began to appear. Thus, Persian architecture is rightly a precursor to Turkic mausoleum architecture in Central Asia, inheriting several pre-Islamic elements.

Table 2. Historical background of the development of early Islamic mausoleum architecture in Persia and Anatolia

\begin{tabular}{|l|l|}
\hline $\begin{array}{l}\text { In the } \\
\text { eleventh } \\
\text { century, }\end{array}$ & $\begin{array}{l}\text { Constructing mausoleums officially became an important part of } \\
\text { Persian architecture and culture. Many of these mausolea were erected } \\
\text { for the honor of famous Sufi dervishes and religious masters, including } \\
\text { the tomb of Bayazid Bastami (first dated structure cca. 1120), a famous } \\
\text { Persian mystic who lived in the ninth century, in Bastam (Persia). } \\
\text { Similar to other mausolea, it was a place for pilgrimage. }\end{array}$ \\
\hline $\begin{array}{l}\text { In the late } \\
\text { thirteenth } \\
\text { and early } \\
\text { fourteenth } \\
\text { centuries, }\end{array}$ & $\begin{array}{l}\text { The building was redecorated with stucco and tiles, also expanded with } \\
\text { the addition of a monumental portal and an enclosing wall and an } \\
\text { Iwan' across the courtyard from the portal, }\end{array}$ \\
\hline $\begin{array}{l}\text { In the } \\
\text { fourteenth } \\
\text { and } \\
\text { fifteenth } \\
\text { century }\end{array}$ & $\begin{array}{l}\text { The mausolea grew to more monumental size, as testified by the } \\
\text { mausoleum of the Ilkhanid Sultan Uljaytu near Tabriz in Western } \\
\text { Persia (c. 1314) and the so-called Gur-i Mir. The mausoleum of Timur } \\
\text { (d. 1405) in Samarqand (Uzbekistan), built in the early fifteenth } \\
\text { century. In this monument, a domed funerary chamber contains the } \\
\text { burials of Timur and several members of his family, creating a dynastic } \\
\text { mausoleum (Rizvi, 2011). }\end{array}$ \\
\hline $\begin{array}{l}\text { With the } \\
\text { advent of } \\
\text { the Safavid } \\
\text { dynasty of } \\
\text { Persia in the } \\
\text { early } \\
\text { sixteenth } \\
\text { century }\end{array}$ & $\begin{array}{l}\text { Royal tombs were concentrated around the shrine of Shaykh Safi at } \\
\text { Ardabil, while other locations such as the shrine of Fatima al-Ma'suma } \\
\text { in Qom were promoted as pilgrimage sites (Rizvi, 2011). Around the } \\
\text { same time, a strong connection between funerary monuments and } \\
\text { gardens was also presented in Mughal India. Mausolea have been } \\
\text { preserved back to the mid-sixteenth century, such as the tomb of } \\
\text { Humayun (r. 1530-1540 and 1550-1556) in Delhi. The most famous of } \\
\text { all is the Taj Mahal (1622-1628), the tomb that Shah Jahan built for his } \\
\text { wife Mumtaz Mahal (Koch, 2006). In this case, the mausoleum is } \\
\text { situated within a garden landscape that is designed to highlight its } \\
\text { structure and to provide a pleasant setting evoking the gardens of } \\
\text { paradise (Gharipour \& Blessing, 2015). }\end{array}$ \\
\hline
\end{tabular}

According to some iconographic analysis, shrines were created as equivalents of paradise, and paradise symbols can be found both in their structure and detailing. One of the oldest forms of this symbolism is a shading tree above the grave, which appears in the plant ornament that appears on the envelope of the structures. At the same time, it can appear in the creation of space, which, like a tree, is a tent formed by the archetype of the roof that gives the tomb a shade, a canopy of domes resting on columns or pillars, or a closed mausoleum of domes resting on walls.

1 which is manifested in a rectangular hall or space, usually vaulted, and walled on three sides, with one entirely opened facade. 
Table 3. The viewpoints of the feature of Islamic mausoleum

2 Chahar-tag is a crossshaped space with a dome cover that sits on the hinges and has four arched entrances (Godard, 1938, pp. 8-10; Boyce, 1975, pp. 463464; Huff \& O'Kane, 1990, pp. 634-642)

3 Inner Asia refers to landlocked regions within East Asia and North Asia

4 Memorial Architecture is the Symbol of Remembrance, Memories, and power

5 covered with domes, sometimes with cones on the outside, various vertical stretches, e.g. Gunbad-i Qābūs, Gurgan, 1007.; Gunbad-i Pīr-i Alamdār, Dāmghān, 1021.; Gunbad-i Chihil Dokhtarān, Dāmghān, 1058.; $\quad$ Gunbad-i Mihmandust, Dāmghān, 1097.; Burj-i Tughril, Rayy, 1139

6 covered with domes, e.g. Mausoleum of Ismail Samani, Bukhara, 10th Century; Mausoleum of Pīr, Takistan, 12th Century

7 covered with domes, e.g Pīr-i Murād, Turanpusht), octagonal (covered with one or two-shell dome, e.g. Gunbad-i Alī, Abarqū, 1038.; Karraqan, 1067

8 with domed interior and polygonal conical outer mass, e.g. Gunbad-i Kābūd, 1197

9 typically domed and polygonal conical outer mass, e.g. Gunbad-i Ghazan Kān, 14th Century. It has a symbolical meaning related to the first twelve imams of Islam

\begin{tabular}{|c|c|}
\hline Ernst Diez, & $\begin{array}{l}\text { The conically roofed tower was a translation into permanent materials } \\
\text { of the royal tent of Central Asian nomads, all of which can be } \\
\text { corroborated by a brick-textured design. Similar ideas are expressed by } \\
\text { Arthur Upham Pope, Eric Schroeder, S.P. Tolstov, Katharina Otto-Dorn } \\
\text { and Emil Esin. (Diez, 1938. p. 926, see also: Azarpay, 1982.p. 9). }\end{array}$ \\
\hline $\begin{array}{l}\text { Katharina } \\
\text { Otto-Dorn }\end{array}$ & $\begin{array}{l}\text { Two-storeyed Anatolian Seljuq kümbets (e.g. Shrine of Malik Gazi in } \\
\text { Kirşehir, 11th century) are related to Central -Asian burial practices. } \\
\text { While the upper space, the cella memoriae (namazgah) symbolizes the } \\
\text { tent where visitors can pay homage to the deceased, the lower chamber, } \\
\text { the hypogeum (cenazelik), represents the burial chamber containing the } \\
\text { body itself (Otto-Dorn, 1979). }\end{array}$ \\
\hline $\begin{array}{l}\text { Andere } \\
\text { Godar }\end{array}$ & $\begin{array}{l}\text { Realizes the formation of Islamic art as being more based on thought than } \\
\text { on the form and technique. He was of the belief that the art should not be } \\
\text { any more taken into account from the perspective of the masonry or } \\
\text { stone and brick or skill and versatility of the artist rather it has to be } \\
\text { known as the mindset and spirit of the nation's community that creates } \\
\text { the artworks or special styles and methods. Godar considers Islamic } \\
\text { architecture, especially in the very beginning of Islam, as being imitated } \\
\text { from the styles of the other civilizations and cultures (Mosavi, 2002). }\end{array}$ \\
\hline Pope & $\begin{array}{l}\text { The mutual effect of Persian culture and art on the other civilizations is } \\
\text { the subject that has been taken into consideration by many of the experts } \\
\text { and researchers and Pope has also dealt with it. But, in his mind, all of the } \\
\text { buildings constructed in Persia feature a Persian personality and nature. } \\
\text { He opines that the preliminary architecture of a historical epoch is surely } \\
\text { influenced by the other civilizations and finds the architecture of the late } \\
\text { era before Islam as effective on the architectural styles of other spots. } \\
\text { The topic that Pope and many of the other historians of Persian art and } \\
\text { architecture believed in was the interaction between Persia's culture and } \\
\text { art with those of the other civilizations though Pope always emphasizes } \\
\text { on the vernacular properties of Persian Art (Pope, 1987). }\end{array}$ \\
\hline $\begin{array}{l}\text { Blair and } \\
\text { Bloom }\end{array}$ & $\begin{array}{l}\text { The oriental culture and civilization are amongst the civilizations } \\
\text { influencing the culture and subsequently the architecture of the other } \\
\text { countries. In their valuable book named "Islamic art and architecture", } \\
\text { Shila Beller and Jonathan Bloom dedicate a part to the title "the effect of } \\
\text { Islamic art" and speak of the continuation of Islamic architecture's effect } \\
\text { on the European architecture (Blair \& Bloom, 2002). }\end{array}$ \\
\hline $\begin{array}{l}\text { Hasani } \\
\text { and } \\
\text { Taghavi }\end{array}$ & $\begin{array}{l}\text { Factors like the Persian population's extensive migration to Anatolia and } \\
\text { the Persian prominent figures and scientists who were avidly needed by } \\
\text { the Seljuq Government assisted the daily increasing inclination of the } \\
\text { Seljuq elders towards the Persian culture. } \\
\text { The present study's findings underline the idea that Persians promoted } \\
\text { culture, rites and rituals and distinct signs of science, art and knowledge } \\
\text { that were common in Seljuq Era's Persia along with their presence and } \\
\text { created many scientific, artistic and literary works. The interaction } \\
\text { between Persians and the Seljuq governors and the auspicious } \\
\text { conditions provided by them, as well, paved the way for the growth and } \\
\text { blossoming of the Persian culture (Hasani \& Taghavi, 2010). }\end{array}$ \\
\hline $\begin{array}{l}\text { Oleg } \\
\text { Grabar } \\
\text { and } \\
\text { Bunakatī }\end{array}$ & $\begin{array}{l}\text { The emphasis on the vertical direction of mass formation can also be } \\
\text { interpreted as a symbolic representation of heaven - thus reaching a } \\
\text { group of tower museums in Persian territories. One of the most } \\
\text { important examples is Gunbad-i Qabūs in Gurgan. The circular plan } \\
\text { building is } 61 \text { meters high and } 17 \text { meters in diameter. The emphasis on } \\
\text { vertical dimensions can be nourished on the one hand -according to Oleg } \\
\text { Grabar - as an important symbol of victory in the reign. But it can be } \\
\text { interpreted as a "ladder to heaven" as described by Bunakati in the } 14 \text { th } \\
\text { century (Daneshvari, 1986). In this point, the further important } \\
\text { archetypes of the mausolea are the Sassanid chahar tag }{ }^{2} \text {, the dakhma and } \\
\text { the imamzade. }\end{array}$ \\
\hline
\end{tabular}

In Turkic-influenced Inner Asia 3 , a wide variety of memorial ${ }^{4}$ architecture spatial types have evolved, with buildings that can form circular ${ }^{5}$ square $^{6}$, hexagonal ${ }^{7}$, decagonal ${ }^{8}$ and dodecagonal ${ }^{9}$. 
The important example of the first category is the first significant, still standing building of Muslim memorial buildings in Central Asia, which can be linked to the Islamic Persian-origin Samanids. Built in the 10th century, the Mausoleum of Ismail Samanī in Bukhara is a square-planned building with a dome, the brick construction gives a unique decorative surface on both the internal and external facades. In the corners of the transition zone between the polygonal space and the raised hemisphere dome, a conical vault gives an essential feature to the building, which thanks to the row of windows running on the facade- gives the unique light effect. The entire building, like a lightly woven tent, rises above the tomb below the floor, creating a closed polygonal basement type of Muslim tomb architecture in Central Asia, with an influence on the architecture of the following ages.

\section{Development of Seljuq mausoleum architecture}

The Seljuq Turks' dynasty was established at the onset of the eleventh century. They always supported and promoted industries and techniques in Persia, Minor Asia, and Iraq (Zaki, 1941). After Seljuq's defeat of Ghaznavid dynasty in $1040 \mathrm{AD}$ and demolishing the Buyid dynasty in Baghdad, they established themselves as new protectors of the Abbasid Caliphate in 1055 AD. Within fifty years, the Seljuqs created a vast empire, encompassing all of Persia, and much of Anatolia. Under the Seljuq sultanate, Persia had a period of material, cultural wealth as well as creativity in art and architecture (Bosworth, 2007).

Christian Wilson writes "in this era, the industries and architecture not only revitalized in Persia but it was also with the Seljuqs' conquers that the principles and styles of Persian industries were expanded and spread to the northern coasts of the Mediterranean Sea and even north of Africa and it is due to the same reason and quality that the Persian artists' artworks and samples of them as well as the common Seljuq Era's industries can be seen for centuries in Egypt and Syria's industries (Wilson, 1938).

In Seljuq Era's constructions, brick is skilfully used in various methods and, corresponding to the traditions, the exterior surfaces of the buildings are offered without any additional coating and with the same brick-laid view that form the trivial decorations of architecture and the elements used therein. Of course, it is worth mentioning that the brick-casting art and decoration of the buildings with well-molded bricks have been common in Persia since the 11th AD and continued till the late 12th AD (Behnam, 1963).

Persia was captured by Khwarazmians with the defeat of Seljuqs in 1142 . Although the Khwarazmians' government was expanded (1078-1231), it became unstable with the outset of the Mongols' attacks. The first raids by the Mongols in 1220 to the Khwarazmians' territory led to the instability of Khorasan and the other regions in Persia. In these attacks, Khorasan, the most important center of knowledge and literature and art, was damaged more than any other places and this same issue caused the 
migration of many Persian scholars and artists to the other lands in Minor Asia that was still held at that time by a group of Seljuqs known as Rumi Seljuqs (1078-1301). Beyond the Persian borders, Seljuqs laid the cornerstone of the establishment of a Turk government in Anatolia (Figure 2). They ruled for nearly three centuries in a vast part of Anatolia in a stretch of land that encompassed various tribes. It was by their socialization that a civilization sprouted, and a government known as Rome's Seljuqs was established. The Seljuq government supported culture and art and created a system that provided the opportunity for the fertilization of culture and art with its enforcement of the reconciliation policy within its realm. However, the architecture of this period can be possibly introduced as one of the most excellent manifestations of this government.

Figure 2. Seljuq Empire in Central Asia and Middle East (Prepared by Authors).

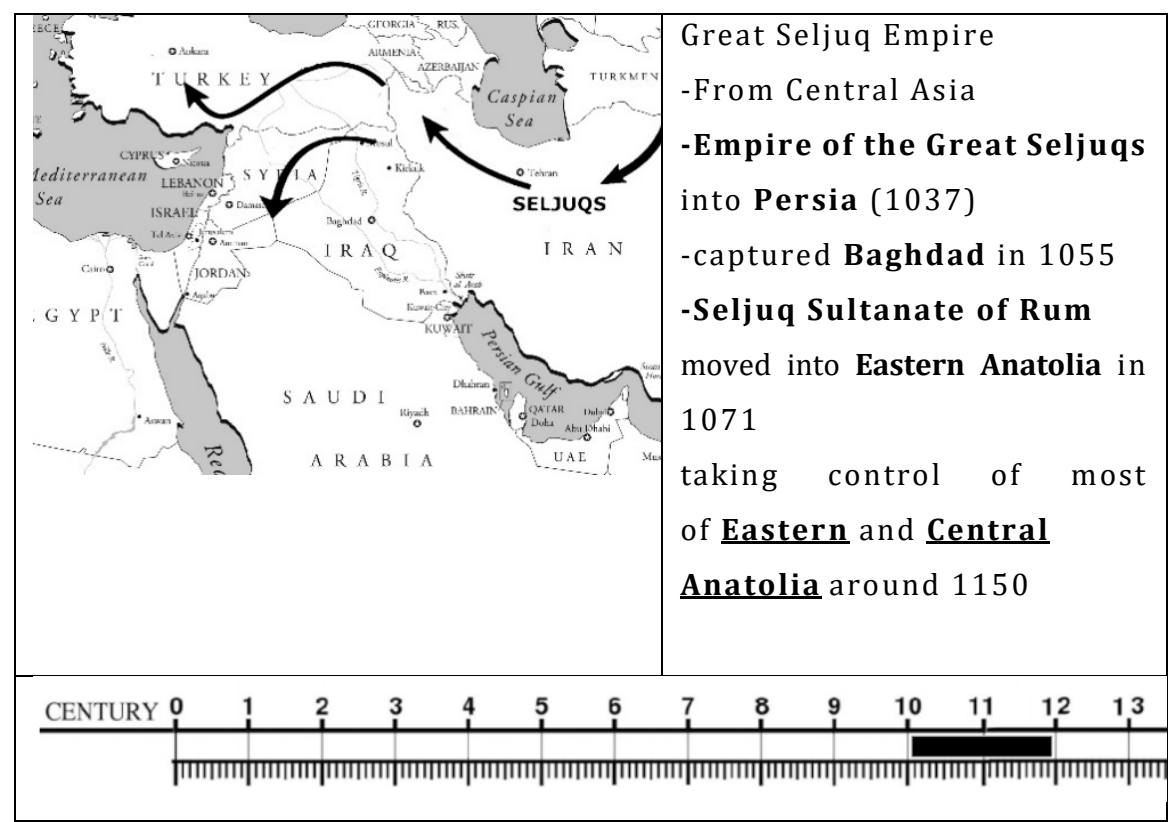

\section{ANALYSIS}

\section{The Revelation on the Origin of Tomb Towers Architecture}

The first type of Persian mausolea belonging to the Samanid princes in Bukhara in the 9th AD, the plan is a domed cube probably influenced by the Sassanid Chahar-tag (Pope, 1976).

The wide distribution of Sassanid shrines throughout Persia during the Islamic victory made this type of architecture an obvious example for the Islamic tombs of Persia. Another feature of the tomb of Amir Ismail Samanid, which reinforces the theory of Persian's architectural style, is the zone of a transition that resolves the issue of transitional rule by Sekonj the square into a circle dome, a transition structure that is common in the Sassanid period.

Another type of shrines in Persia is formed by the group of tomb towers. Its origins lie in a veil of mystery. Due to the prevalence of these tombs in northern and north-eastern parts of Persia, some scholars refer to them as Turkish tents or Chinese watchtowers (Daneshvari 9, 2011). Their 
predominant form is a tall cylinder with a cone-shaped roof, the first surviving example of which is the Gabus dome (1006 AD). Tomb towers were common from the late fourteenth to the early eighth century (on the arrival of the Ilkhanids). Therefore, two types of architectural features of the mausoleum in Persia are tomb towers and Dome Cube. It is important to note that the octagonal plan shape is found in both types (Figure 3). Over time, the incarnation of the early form of tomb architecture that was the building of the domed cube has evolved into a result of intellectual evolution as a dome-shaped octagon (Kiani 70, 2009.).

On the other hand, Minaret is a specific physical element in Islamic architecture, which has an ancient record in pre-Islamic Persian architecture. A host of theories concerning the initiation of minaret could be found in contemporary debates of Architecture. In this article, ziggurats, huge buildings in Mesopotamian civilization, and one of the essential religious constructions of civilization history, are considered as the progenitors of our minarets. Because of the changes in human perception of religion and in association with domestic architectural patterns, this architectural element has faced various changes, both in form and function, in different regions and different rituals. Some experts believe that Minaret had been a sort of milestone used as a guiding symbol in ancient routes of pre-Islamic Persia or it could have been the sign of huge traditional sacred fireplaces in that era. In addition, there could be found some ideas that insist on the religious role of Minaret even in pre-Islamic Persia as the main trait of it, not its function as a milestone. This element has achieved an important role in Islamic architecture, to the point that along with domes and gates, minarets have been considered as the main landmarks to enhance the legibility of Islamic cities. Kiani believes that the oldest samples of Minaret are the Persian Pre-Islamic milestones such as Firouzabad milestone and Mamasani milestone in southern Persia and some others in central mosques of Damishgh, Syria and Samerah, Iraq (Heydari, 2008).

The Gonbad-e Gabus at Gurgan in Persia (1007 A.D.) is the earliest tomb tower (over 1000 years old) with a solid conical shell. It is the largest Seljuq dome with a $9.7 \mathrm{~m}$ span and $57 \mathrm{~m}$ height (Figure 3 ). Monumentally, its style holds an important place in the Seljuq architecture (Pope 1976), which was used later as a model for developing cylinder or cube-based forms throughout Persia and surrounding areas (O'Kane 1998; Saoud 2003).

Based on the evidence, two significant Factors affecting the deformation and function of Gonbad-e Gabus in the Seljuq period, desire to build magnificent monuments and Rulers and architects were familiar with majestic architecture and Geometry before the advent of Islam in Persia, so it can be argued that the architect in the design of the Gabus tomb Tower was inspired by the glory of the minaret that was common in Persia. 
Comprehensive Revelation on the Tomb Towers Architecture; Persia and Anatolia

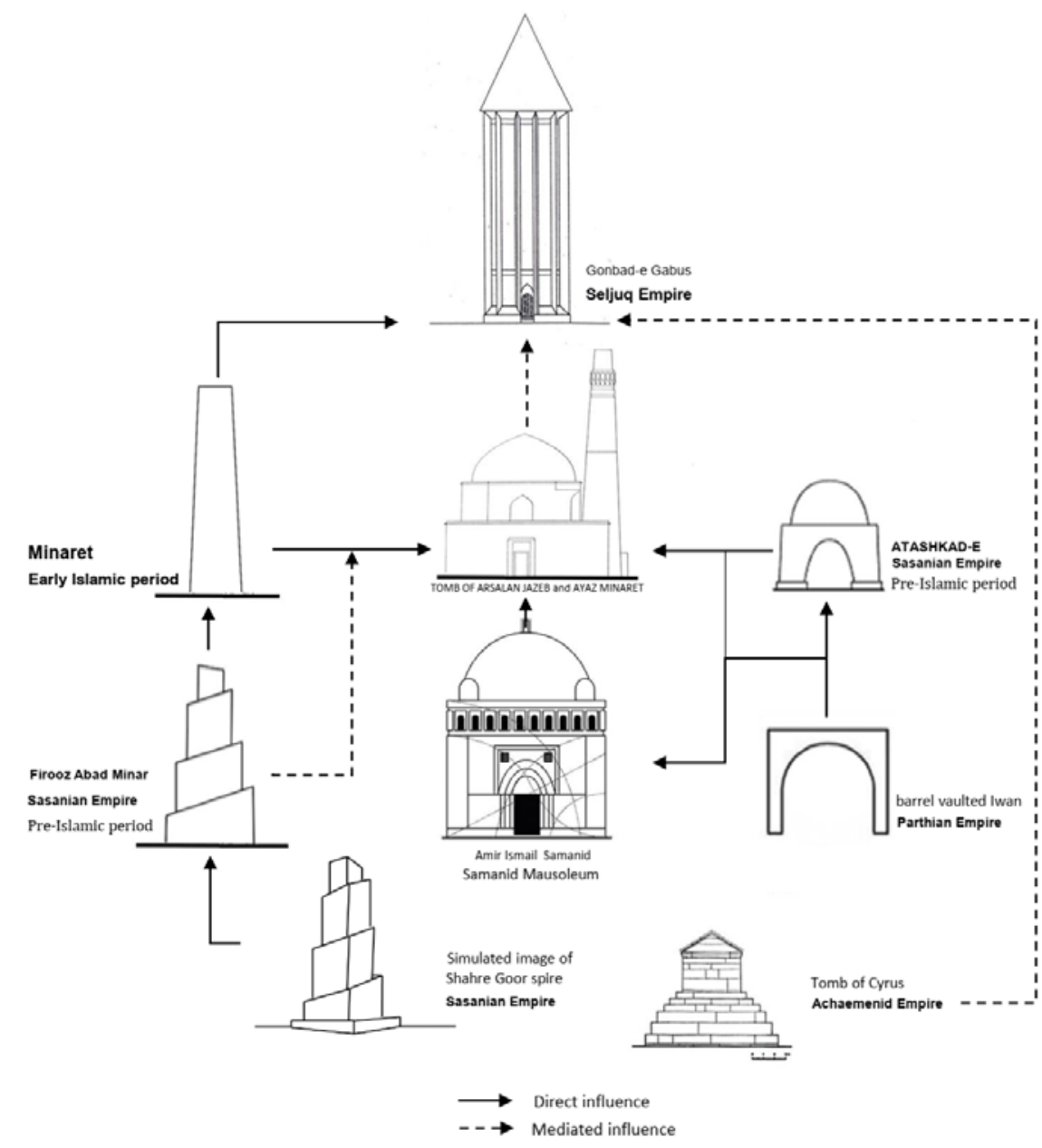

towers The origin of Tom (Prepared by Authors).

Figure 4. Timetable of Persian empire (Prepared by Authors).

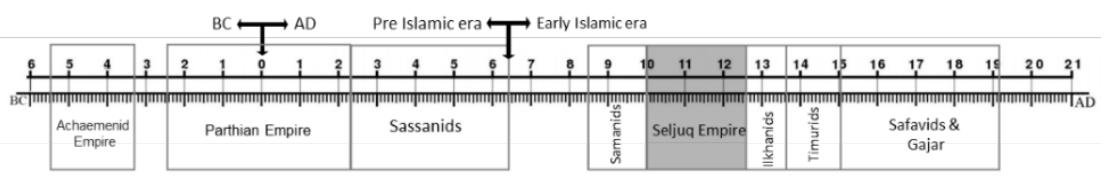

Early Islamic Mausoleum Architecture in Persia

Figure 5. Early Islamic Tomb towers in Persia (Prepared by Authors).

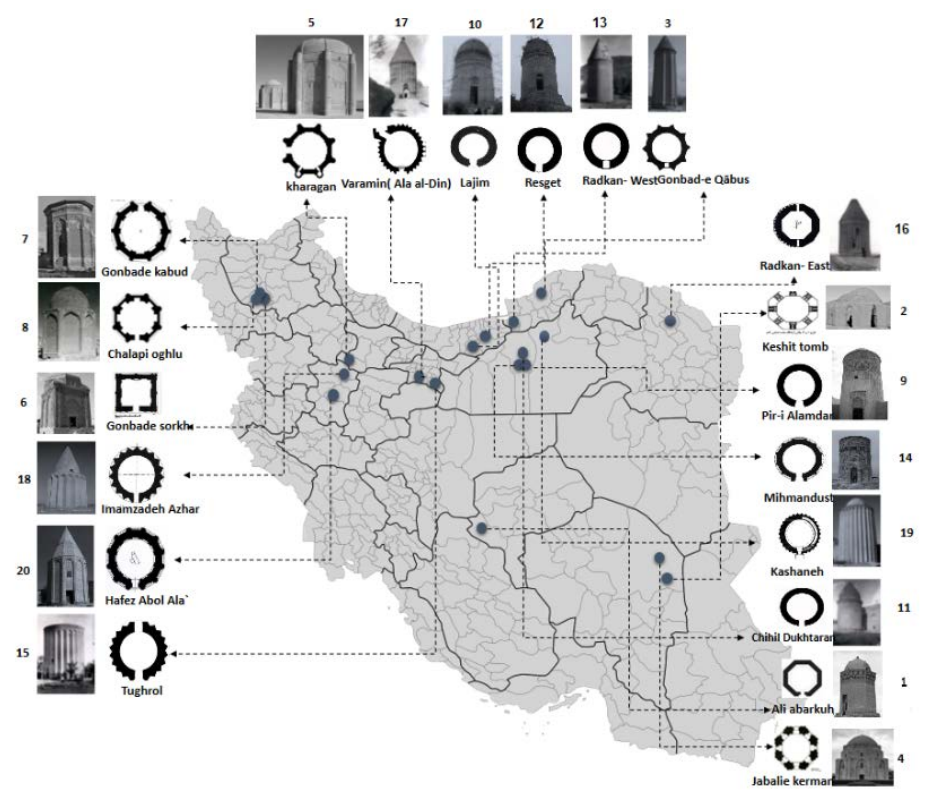


Zeynab Nazer \& Gergő Máté Kovács \& Péter Rabb

Table 4. Construction feature of Persian tomb towers (Prepared by Authors)

810

\begin{tabular}{|c|c|c|c|c|c|c|c|c|c|c|c|c|c|c|c|}
\hline & $\begin{array}{c}\text { है } \\
\stackrel{0}{0}\end{array}$ & $\vec{B}$ & $\begin{array}{l}\frac{\pi}{2} \\
\frac{\pi}{2} \\
\frac{0}{0} \\
\frac{0}{x}\end{array}$ & 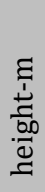 & 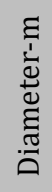 & 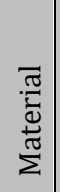 & 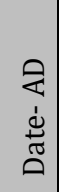 & & $\begin{array}{l}\text { है } \\
\text { }\end{array}$ & 䆑 & $\begin{array}{l}\frac{\pi}{2} \\
\frac{\pi}{2} \\
\frac{0}{0} \\
\frac{0}{1}\end{array}$ & 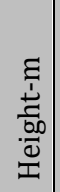 & 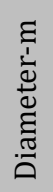 & 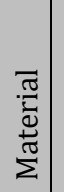 & $\begin{array}{l}8 \\
\dot{d} \\
\dot{\pi} \\
0\end{array}$ \\
\hline 1 & $\begin{array}{l}\frac{a}{\vec{z}} \\
\frac{\vec{z}}{\pi} \\
\frac{\pi}{\pi} \\
\frac{\pi}{\pi} \\
\vec{z}\end{array}$ & 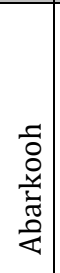 & & $\approx$ & $\stackrel{\sigma}{\infty}$ & 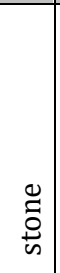 & $\begin{array}{l}\text { 늠 } \\
\stackrel{2}{0} \\
\rightarrow\end{array}$ & 11 & 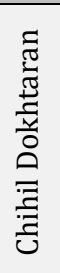 & 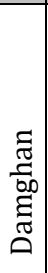 & & $\stackrel{2}{\rightarrow}$ & $\stackrel{m}{\sim}$ & $\begin{array}{l}\stackrel{u}{\vec{n}} \\
\dot{n}\end{array}$ & $\begin{array}{l}\text { ㅇํㄱ } \\
\stackrel{-}{\circ}\end{array}$ \\
\hline 2 & 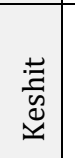 & 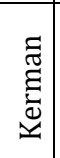 & & . & 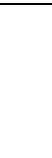 & $\begin{array}{l}\stackrel{M}{\breve{L}} \\
\dot{m}\end{array}$ & $\begin{array}{l}\tilde{1} \\
\stackrel{1}{0}\end{array}$ & 12 & $\begin{array}{l}\vec{U} \\
\infty \\
0 \\
\simeq \\
\simeq\end{array}$ & 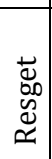 & & $\underset{\sim}{\sharp}$ & $\stackrel{+}{6}$ & 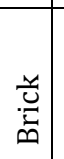 & $\begin{array}{l}\text { I } \\
\stackrel{-}{F}\end{array}$ \\
\hline 3 & $\begin{array}{c}0 \\
z \\
\frac{0}{10} \\
0 \\
0 \\
i \\
\tilde{0} \\
0 \\
\tilde{0} \\
0 \\
0\end{array}$ & 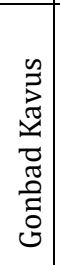 & & 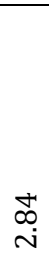 & $\begin{array}{l}\overrightarrow{7} \\
\stackrel{7}{-}\end{array}$ & 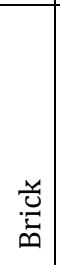 & \begin{tabular}{l}
0 \\
$\stackrel{0}{0}$ \\
\hdashline
\end{tabular} & 13 & 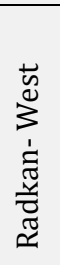 & 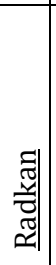 & & $\underset{\stackrel{\sim}{*}}{\stackrel{N}{N}}$ & $\ddot{\sigma}$ & $\begin{array}{l}\frac{y}{\breve{v}} \\
\stackrel{n}{n}\end{array}$ & \\
\hline 4 & $\begin{array}{l}\overline{\tilde{\Xi}} \\
\tilde{\widetilde{\Omega}}\end{array}$ & 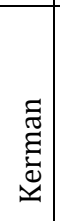 & & & & 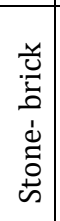 & & 14 & 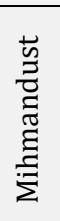 & 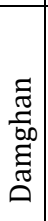 & & $\underset{\sigma}{m}$ & $m_{\sigma}^{m}$ & 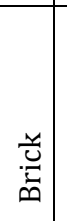 & $\hat{g}$ \\
\hline 5 & 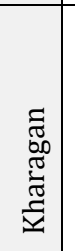 & $\begin{array}{l}\sqrt[5]{5} \\
\mathbb{J} \\
\mathbb{J}\end{array}$ & & & $\stackrel{2}{\sim}$ & $\begin{array}{l}\stackrel{y}{\vec{U}} \\
\stackrel{D}{D}\end{array}$ & $\exists$ & 15 & 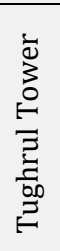 & $\stackrel{\vec{Q}}{\approx}$ & & $\stackrel{\sim}{\circ}$ & $\stackrel{0}{\sim}$ & $\begin{array}{l}\stackrel{y}{\breve{L}} \\
\dot{\mathscr{n}}\end{array}$ & 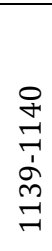 \\
\hline 6 & 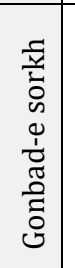 & 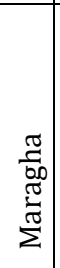 & & & $\exists$ & $\begin{array}{l}\frac{M}{\breve{M}} \\
\dot{\bar{n}}\end{array}$ & $\stackrel{\theta}{1}$ & 16 & 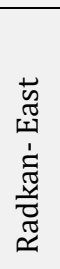 & 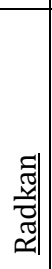 & & $\stackrel{\llcorner}{N}$ & $\begin{array}{l}\stackrel{m}{m} \\
\stackrel{n}{n}\end{array}$ & $\frac{\ddot{u}}{\vec{D}}$ & 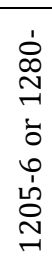 \\
\hline 7 & 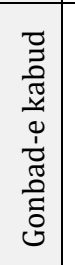 & $\begin{array}{l}\frac{\pi}{60} \\
\pi \\
\tilde{\pi} \\
\Sigma \\
\Sigma\end{array}$ & & & $\stackrel{m}{\rightarrow}$ & 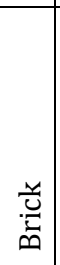 & $\stackrel{\circ}{-}$ & 17 & 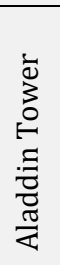 & 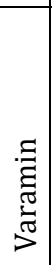 & & $\stackrel{\bullet}{\sim}$ & $\begin{array}{l}0 \\
\stackrel{]}{J}\end{array}$ & $\begin{array}{l}\stackrel{y}{\breve{E}} \\
\dot{\bar{n}}\end{array}$ & 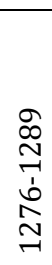 \\
\hline 8 & $\begin{array}{l}\vec{z} \\
\overrightarrow{0} \\
0 \\
-\overrightarrow{0} \\
\frac{\pi}{\pi} \\
\frac{\pi}{v}\end{array}$ & 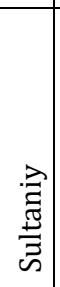 & & & & 总 & & 18 & 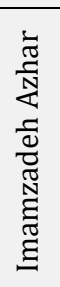 & 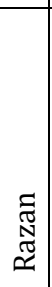 & & $\stackrel{\sim}{ }$ & $\sigma$ & 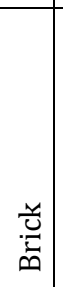 & \\
\hline
\end{tabular}




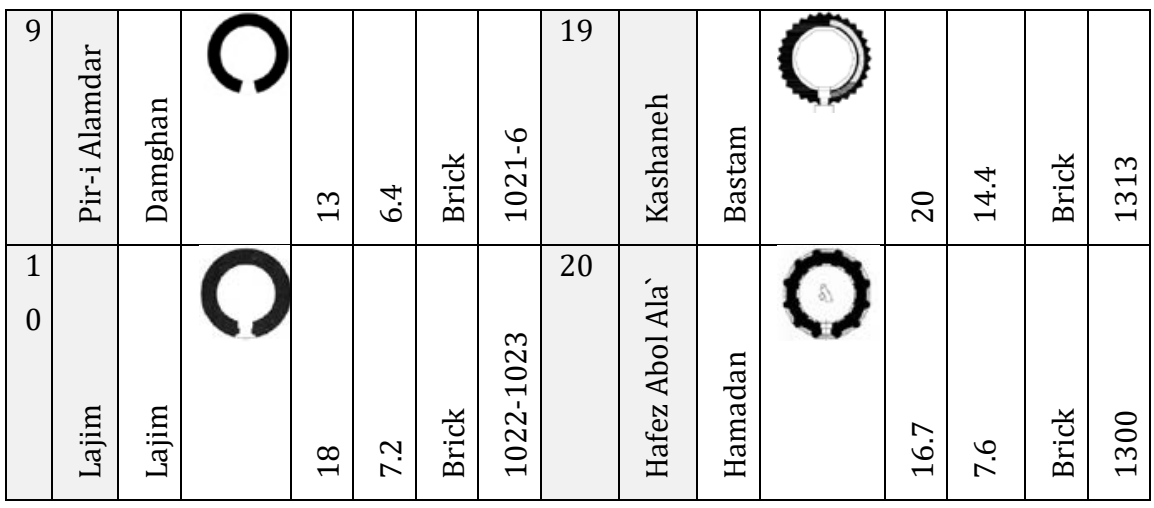

\section{Seljuq Mausoleum Architecture in Anatolia}

With the Anatolian appearance of the Seljuqs, the type of building from the Persian territories that preserves the pre-Islamic architectural idea also appears on the Anatolian Peninsula. The earliest kümbets are connected to the Danismendida dynasty from 1071 to 1178, whose main centres are the cities of Eastern Anatolia: Sivas, Kayseri, and Malatya.

The features of the early Anatolian Seljuq kümbets are the spatial formation with one-storey tombs with an inner space only above the ground, and the two storied buildings with a funeral chamber and a memorial space. The funeral chamber was typically constructed not underground, but to the ground. The former burial chamber is typically square, rarely octagonal, whereas the upper space is hexagonal, octagonal, decagonal (e.g. Kümbet of II. Kılıçarslan in Konya, 12th Century) or dodecagonal, moreover, the circular plan is also typical. The space was covered with domes in the interior, pyramidal or conical mass in the outer space. Therefore, a wide variety of space formation was typical in the Seljuq architecture of Anatolia.

Special mention should be made of the kümbets in Ahlat as a cohesive group of buildings, each of which has a two-storey, circular-planed interior with a dome with a cone-like appearance.

These examples are typically part of a building complex where the grave of the founder of the building group is located. Exceptions to this are mosques - as there are burials in the foreground of the mosque. The Kümbet of Mama Hatun, which was built in Tercan in the early 13th century, is a unique monument both in space and in its complex of buildings. The focal point of the building complex is two-storey: the cryptspace (cenazelik) is an eight-arched cone-shaped tomb tower with a memorial space (namazgah). The building is bordered by a circular plan wall with internal niches on the inside.

Although these buildings retain a number of Central Asian traditions in terms of space and structure, the difference consist significantly in the material. While brick was the prime building material for former buildings, including the Seljuq examples in the Persian territories, stone architecture - usually the natural stone - plays a decisive role in Anatolian Seljuq architecture. There are, of course, exceptions: the 15th-century mausoleum of Zeynal bey, located in Gunbad Ali (1055) near Jazd in central Persia, and Kümbet of Zeynel bey in Hasankeyf in south-eastern 
Turkey, in which case it gives a similar pattern, which is decorated with glaze ceramic along the lines of the gate and the ledge. The latter building has been completely rebuilt due to dam construction. In Anatolian Seljuq architecture, the exclusive use of brick is typically found in minarets.

The architectural use of glazed tile artwork of Chinese origin is typically found in Anatolia, with the contribution of Seluqs, mainly in the form of glazed decorative elements embedded in masonry. The Seljuq memorial buildings are richly ornamented almost without exception, and their exterior features a variety of ornamentation. The decorations typically appear around the gate, in the case of a polygonal floor plan, on the framing of each facade and on the crown cornice. In the case of floral ornaments, which are usually planted, we can identify the idea of Paradise. One of the important origins of the ornaments is due to the rich surface decoration in the architecture of the Caucasus. The floral motifs sometimes contain imaginary creatures, as well as the Anatolian Hittite power symbol, the one-headed and the two-headed eagle. In addition, there are many Central Asian ornaments - which also depict human or animal are the traits of "Eurasian animal style", personalization of planets, constellations, hunting scenes, hunting animals, human figures in a sitting position, symbolizing the change of the seasons can be seen as a lion and a bull, a dragon with an intertwined body (Gerelyes, 2007).

The surface decoration made of masonry of the wall structure often draws a ribbon-like motif or inscription. The interior and exterior surfaces of both areas are adorned with elements of masonry, often rich in fabrics or lace, as evidenced in the 14th-century stone building of Hüdavend Hatun in Niğde. Thus, these buildings retain a rich interior decoration, both in the Anatolian, Caucasian, and pre-Islamic Inner Asia.

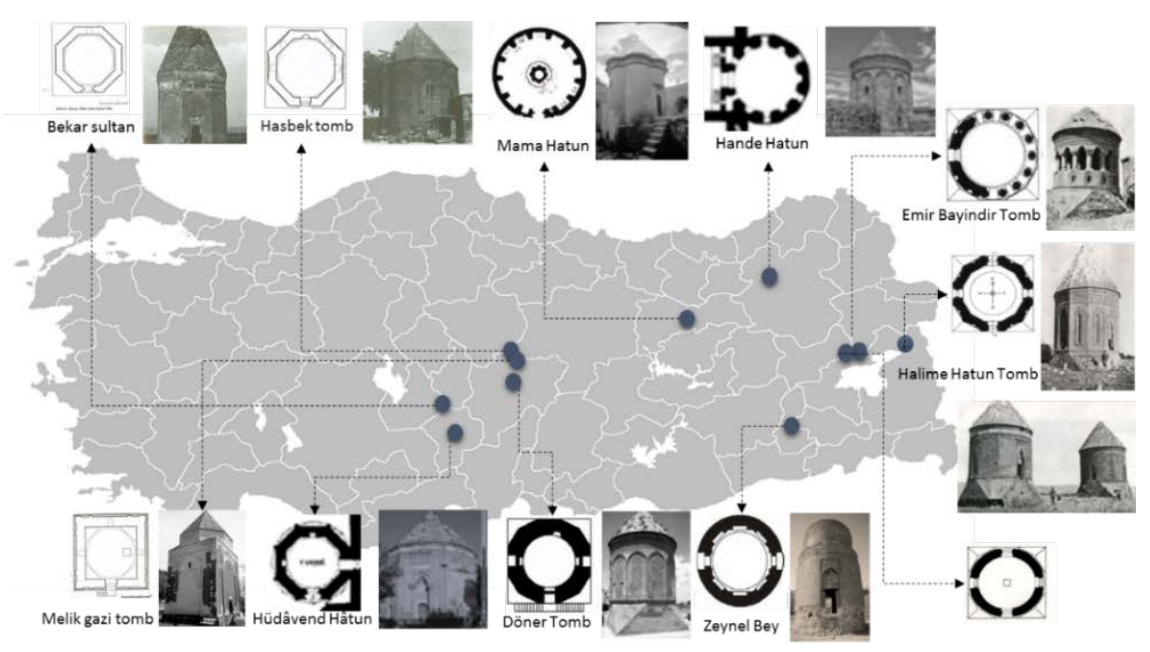

Figure 6. Tomb towers in Anatolia (Prepared by Authors). 
Comprehensive Revelation on the Tomb Towers Architecture; Persia and Anatolia

Table 5. Construction feature of Anatolian tomb towers, Source: authors archive and (Onkal, 1996)

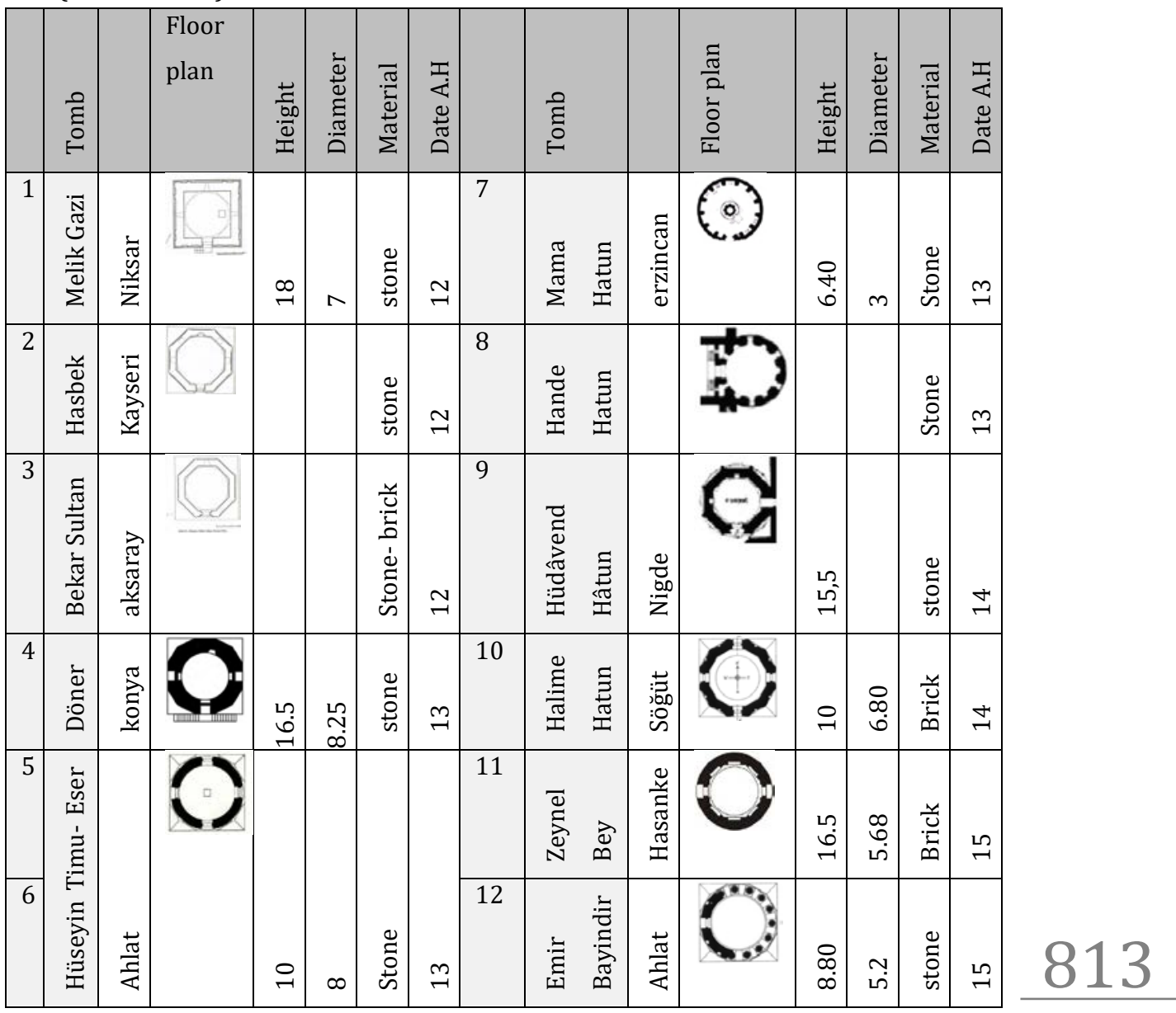

The Influence of Persian- Seljuq Mausoleum on Formation of the Anatolian- Seljuq Mausoleum Architecture

In Anatolia, Greek and Byzantine history on the one hand, the influence of the Achaemenid empire and the Sassanid era of Persia on the other hand and with its Asian history, eventually surpassed the Seljuq era and brought the Ottoman period, so the influence of Persian architecture roots on Anatolian architecture can be deduced.

Following the Seljuq conquest of Anatolia in the late eleventh century, the construction of a tower-shaped mausoleum with conical roofs took hold there as well. Even though no examples have survived from this earliest period of Islamic rule in Anatolia, examples from the twelfth and thirteenth centuries are numerous (Figure 7). 


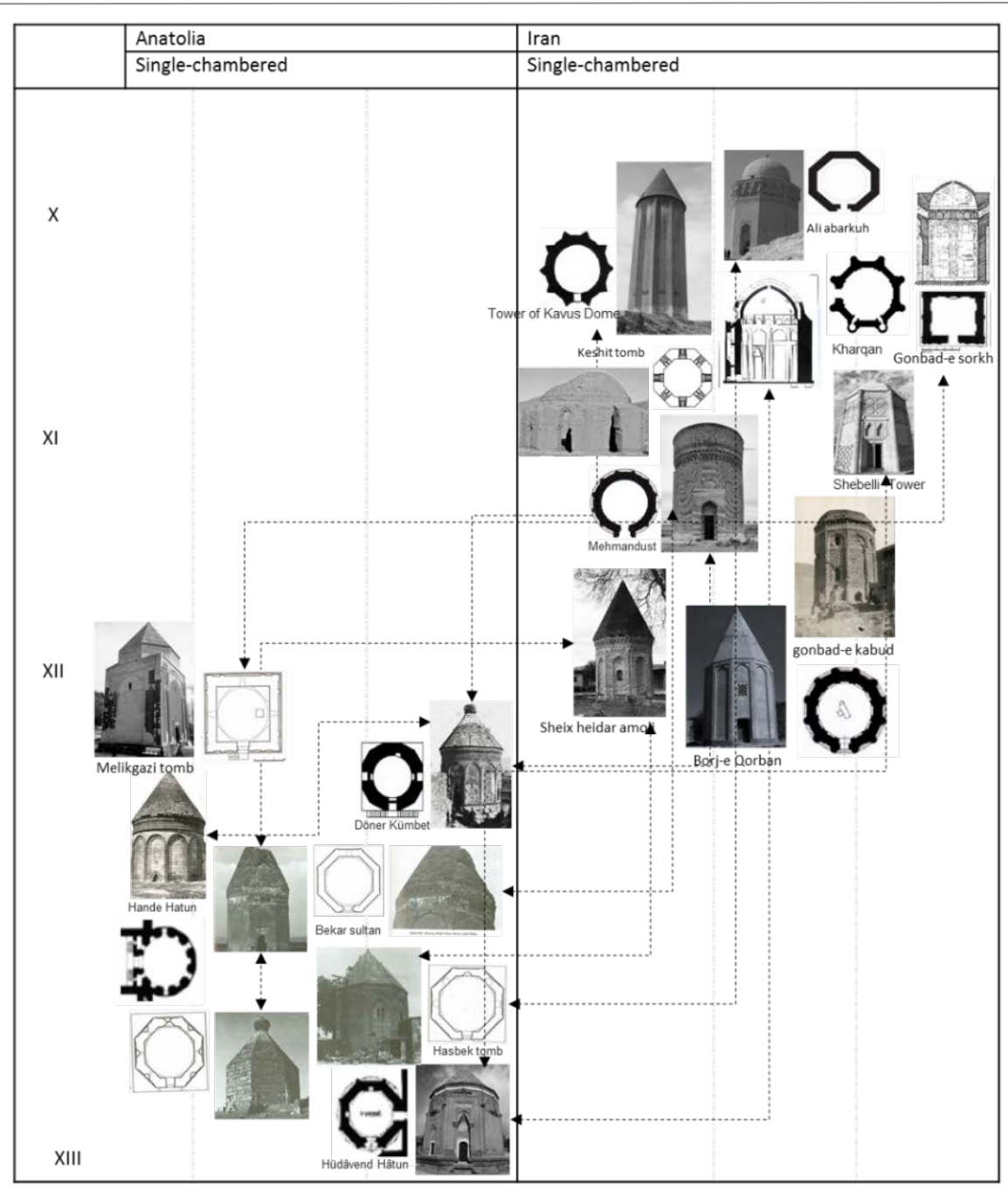

\section{DISCUSSION}

According to the previous historical overview, the Anatolian Seljuq shrine architecture has a close historical relationship with the mausolea in Persia. However, it is an important question, if the similarity can be demonstrated in architectural (spatial and structural) way. Therefore, an analysis method is suggested, in which the buildings are deconstructed to its most important features and investigated in matrices. Then, the morphological and constructional analysis can be made in an objective mathematical way.

In the following analysis, the most common case studies that can cover major part of tomb towers type in Persia $(A=$ Ali abarkuh, $B=$ Gonbad-e Qābus, $\mathrm{C}=$ Kharagan Tomb, $\mathrm{D}=$ Mehmandust, $\mathrm{E}=$ Gonbad-e Kabud, $\mathrm{F}=$ Gonbad-e Sorkh) and Anatolia ( $\mathrm{A}^{\prime}=$ Melik Gazi Tomb, $\mathrm{B}^{\prime}=$ Döner Tomb, $\mathrm{C}^{\prime}=$ Hande Hatun, D'= Bekar Sultan Tomb, E'= Hasbek Tomb, F'= Hüdâvend Hâtun Kümbet) are selected in chronological order and categorized based on structural decomposition (Table 3).

The spatial and structural elements, in which the buildings are deconstructed are the following: the polygon of the plan, the shape of the dome, transitional zone, main body, and storey - if it exists. The twelve
Figure 7. The influence of Persian- Seljuq mausoleum on Formation of architecture of the Anatolian- Seljuq mausoleum (Prepared by Authors). 
Comprehensive Revelation on the Tomb Towers Architecture; Persia and Anatolia

examples from both the territories of Persia and Anatolia are deconstructed to these elements.

Table 6. Structural decomposition in chronological order (Prepared by Authors)

10 Geometrical images have been evaluated according to figure 7 based on decoration.

11 Proportion has been evaluated based on dimension according to table 1 and 2.

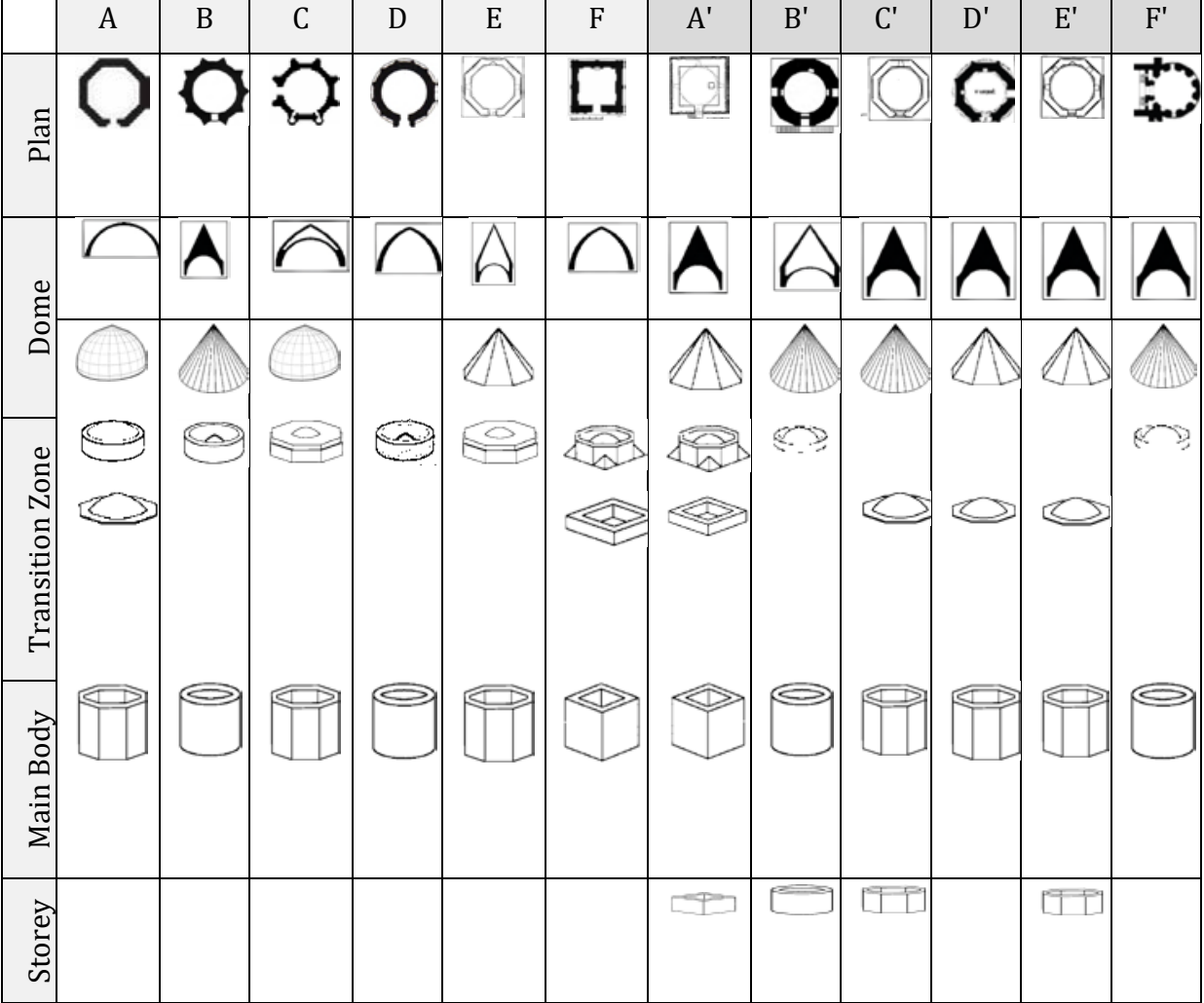

Table 8. Analysed by matrices (Prepared by Authors)

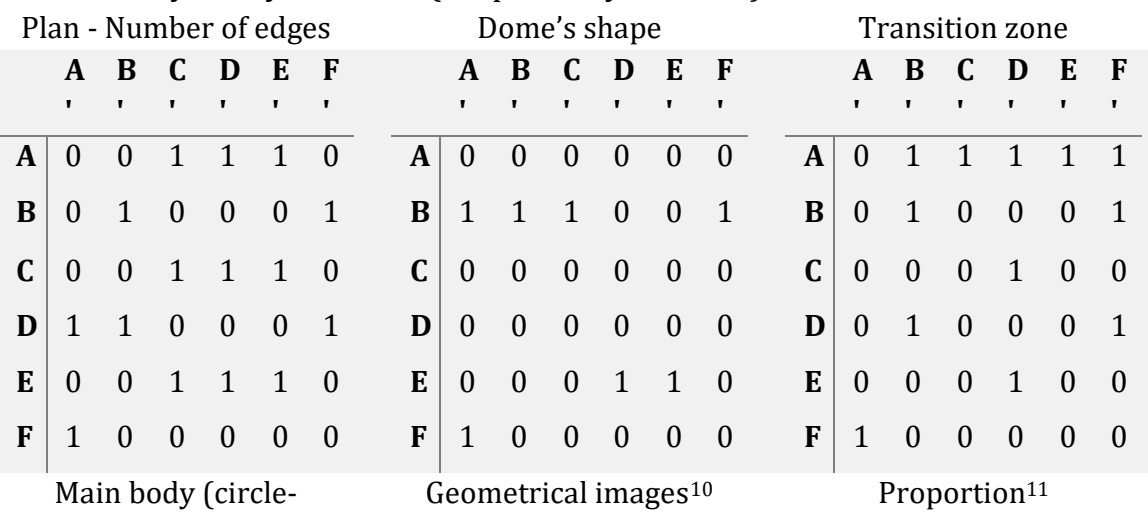

rectangle- polygon)

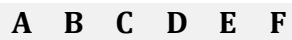

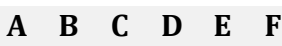

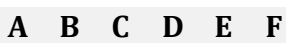

\begin{tabular}{|c|c|c|c|c|c|c|c|c|c|c|c|c|c|c|c|c|c|c|c|c|}
\hline $\mathbf{A}$ & 0 & 0 & 1 & 1 & 1 & 0 & $\mathbf{A}$ & 0 & 0 & 1 & 1 & 0 & 0 & $\mathbf{A}$ & 0 & 0 & 1 & 0 & 0 & 0 \\
\hline B & 0 & 1 & 0 & 0 & 0 & 1 & B & 0 & 1 & 0 & 0 & 0 & 0 & B & 0 & 0 & 0 & 0 & 0 & 0 \\
\hline C & 1 & 0 & 1 & 1 & 1 & 0 & C & 0 & 0 & 0 & 1 & 1 & 1 & C & 0 & 0 & 0 & 1 & 1 & 1 \\
\hline D & 0 & 1 & 0 & 0 & 0 & 1 & D & 1 & 1 & 1 & 0 & 0 & 1 & D & 1 & 1 & 0 & 0 & 0 & 0 \\
\hline $\mathbf{E}$ & 1 & 0 & 1 & 1 & 1 & 0 & $\mathbf{E}$ & 1 & 1 & 0 & 0 & 1 & 1 & $\mathbf{E}$ & 0 & 0 & 1 & 0 & 1 & 0 \\
\hline $\mathbf{F}$ & 1 & 0 & 0 & 0 & 0 & 0 & $\mathbf{F}$ & 1 & 0 & 0 & 0 & 0 & 0 & $\mathbf{F}$ & 1 & 1 & 0 & 1 & 0 & 0 \\
\hline
\end{tabular}


These features were summarized and represented in matrices (Table 7), To evaluate the comparison between the dominant type of architecture in these territories, number 1 mentioned to similarities and number 0 to differences.

Subsequently, the similarities and differences of the examples analysed by matrices according to the features (Table 4). Finally, the similarities are summarized in one matrix (Table 5).

Table 9. Collection of similarities (Prepared by Authors)

\begin{tabular}{|c|c|c|c|c|c|c|}
\hline & $\mathbf{A}^{\prime}$ & $\mathbf{B}^{\prime}$ & $\mathbf{C}^{\prime}$ & $\mathbf{D}^{\prime}$ & $\mathbf{E}^{\prime}$ & $\mathbf{F}^{\prime}$ \\
\hline $\mathbf{A}$ & 0 & 1 & 5 & 4 & 3 & 1 \\
\hline B & 1 & 5 & 1 & 0 & 0 & 4 \\
\hline C & 1 & 0 & 2 & 5 & 4 & 2 \\
\hline D & 3 & 5 & 1 & 0 & 0 & 4 \\
\hline $\mathbf{E}$ & 2 & 1 & 2 & 3 & 5 & 1 \\
\hline $\mathbf{F}$ & 6 & 1 & 0 & 1 & 0 & 0 \\
\hline
\end{tabular}

It can be ascertained that conical, pointed and polyhedral domes are one of the distinctive aspects of Persian domes which constitute an essential milestone in the development of funerary monuments as a cultural tradition after the appearance of Islam in Persia and surrounding areas (Ashkan, 2012). One of the most enduring signs of Seljuq architecture is the distinct types of conical and pointed domes which still stand in Azerbaijan, Turkey, Persia, Turkmenistan, and Uzbekistan. In the Anatolian district of the Seljuq Empire, tomb towers were structurally distinguished from the Persian ones through the deep influences of Armenian models (Stierlin, 2002). According to Hillenbrand (1999), these tomb towers, in some aspects preceded Persian samples as a model in which either pyramidal or conical shells rested on either cylindrical or polygonal bases.

We can see a wide variety of constructional and spatial possibilities. Almost all the possible variations can be demonstrated, therefore the rich architectural formation is visible. The shrine architecture of Anatolia has had the closest correlation with the Persian ones based on the morphological and constructional analysis. According to the summary matrix (Figure 5) it also can be observed, that the most similarity is in the number of edges, and the main body. The less similarity can be seen in the shape of domes. Therefore, it can be determined that besides the general similarity of the two building groups, the main difference between the Anatolian and Persian Seljuq mausolea is in the construction and shape of the dome.

In most cases the direct links between the two building groups could be determined. Even though in all the architectural features similarities could be detected, the main similarities are structural and spatial, and the fewer similarities are in the level of the motifs, the geometrical image (Table 6). 
Table 10. General spatial and structural comparison (Prepared by Authors)

\begin{tabular}{|c|c|}
\hline \multirow{5}{*}{$\begin{array}{l}\text { from the } \\
\text { spatial point of } \\
\text { view }\end{array}$} & similar plans and polygons \\
\hline & $\begin{array}{l}\text { compositional articulation between the cubic base and the cylindrical } \\
\text { bearing system }\end{array}$ \\
\hline & varying degrees of ornament \\
\hline & the use of an exterior ring of blind arches \\
\hline & heights of the tomb tower \\
\hline \multirow{4}{*}{$\begin{array}{l}\text { from the } \\
\text { structural } \\
\text { point of view }\end{array}$} & use of local stone rather than bricks \\
\hline & different types of transition zone \\
\hline & surround the body of the tomb tower with a triangular peel \\
\hline & stem of dome between the dome and the main body \\
\hline \multirow{2}{*}{$\begin{array}{l}\text { from cultural } \\
\text { and climatical } \\
\text { point of view }\end{array}$} & use of different floors for burial \\
\hline & $\begin{array}{l}\text { common type of polyhedral dome's shape rather than pointed and } \\
\text { conical dome - different constructions and shape of dome }\end{array}$ \\
\hline
\end{tabular}

\section{CONCLUSION}

In the paper, the case studies of Persian and Anatolian Seljuq mausoleum architecture were analysed. Since the several historical links of the two building groups have been summarized, it is important to research the manifested architectural evidence. Therefore, after the definition of the main spatial, constructional, and morphological elements, a mathematical chart was introduced. This offers a possibility to set up an algorithmic system to detect the similarities and differences between the Persian and Anatolian Seljuq buildings in an objective way.

As determined by the authors, the roots of the Islamic mausoleum architecture lead to the pre-Islamic ancient architecture. Subsequently, following several major compositional types of Persian and Anatolian mausoleums were formed and later became standard i.e.- Chahar-tag, polygonal, cone -domed ones, and influenced Anatolian mausoleums architecture.

In accordance with this, the origin and main ways of forming the tomb tower in the territory of Persia and Anatolia was as follows - from Persian Pre-Islamic architecture (Chahar-tag, minaret) compositions up to Seljuq's tomb tower architecture, also compositional features and specifics of the monuments of the main regional centers were revealed in the article.

This can prove the conjecture, that the main architectural features are slowly changed, and the bases are similar, and the decorations can be changed more quickly and in a more variable way. The research also points out that almost all the possible spatial and structural variations have been manifested in a wide range of variations and combinations, in the early mausoleum architecture. Despite the similarities in the polygon of the plan, there are more differences in the construction and shape of domes.

This methodology has been set up for a specific example, therefore it is an important task to prove it in the case of further building groups in the future. 


\section{CONFLICT OF INTEREST}

No conflict of interest was declared by the authors.

\section{FINANCIAL DISCLOSURE}

The authors declared that this study has received no financial support.

\section{ETHICS COMMITTEE APPROVAL}

Ethics committee approval was not required for this article.

\section{LEGAL PUBLIC/PRIVATE PERMISSIONS}

In this research, the necessary permissions were obtained from the relevant participants (individuals, institutions, and organizations) during the survey, in-depth interview, focus group interview, observation, or experiment.

\section{REFERENCES}

Ashkan, M., Ahmad, Y. (2012). Significance of Conical and Polyhedral Domes in Persia and Surrounding Areas: Morphology, Typologies and Geometric Characteristics. Nexus Network Journal, 14(2), 275-290.

Azarpay, G. (1982). The Islamic Tomb Tower: A Note on its Genesis and Significance. In A. Daneshvari (Ed.), Essays in Islamic Art and Architecture in Honor of Katharina Otto-Dorn. (pp. 9-12). Malibu.

Behnam, E. (1963). Red Dome of Maragheh. Honar va Mardom, Tehran, 8, 2-6, p. 4.

Blair, Sh., \& Bloom, J. (2002). The Art and Architecture of Islam 12501800. Pelican, p. 345.

Bosworth, C. E. (2007). Historic cities of the Islamic world. Leiden, p. 280.

Boyce, M. (1975). On the Zoroastrian Temple Cult of Fire, Journal of the American Oriental Society, 95(3), 454-465.

Creswell, K. A. C. (1952). The Muslim Architecture of Egypt I. Ikhanīds and Fātimids, A.D. 939-1171. Oxford University Press. p. 113.

Daneshvari, A. (1986) Medieval Tomb Towers of Iran. An Iconographical Study. Mazdâ. p. 14.

Daneshvari, A. (2011). Tower Tombs of Iran in Middle Centuries (The Study of Image Cognitive). Translated by Javad Nayestani and Zohre Zolfaghar Kandri. Samt.

Diez, E. (1938). The architecture of the Islamic period: the principles and types. In A.U. Pope \& P. Ackerman (Eds.), A Survey of Persian Art. (3rd vol., pp. 916-929). Oxford University Press.

Gerelyes, I. (2007). Szeldzsuk művészet [Seljuq Art]. In: Fajcsák, Gy. (Ed.), Keleti Művészeti Lexikon. [Encyclopaedia of Oriental Art]. Corvina. 301.

Gharipour M. \& Blessing, P. (2015). Mausoleums of the Islamic World. In: H. S. Springer (Ed.), Encyclopaedia of the History of Science, Technology, and Medicine in Non-Western Cultures (Third ed.). Springer.

Godard, A. (1938) 'Les Monuments Du Feu' in Athar-e Iran: Annales du Service Archeologique de L' Iran, tome III, Jon. Enschede en Zonen, 7-82. 
Hasani, A., \& Taghavi, F. (2010). Iranian Brokers in the Rom Seljuq Office. Maskoeye. Tehran, 3, p. 104.

Heydari, M.M. (2008) A re-search on minaret. Honar-ha-ye-Ziba 34, 4958.

Hillenbrand, R. (1999). Islamic Art and Architecture. Thames \& Hudson.

Huff, D. \& O’Kane, B. (1990). Čahārtāq, In: Encyclopædia Iranica, Vol. IV, Fasc. 6, 634-642. Retrieved May 15, 2020, from http://www.iranicaonline.org/articles/cahartaq

Kiani, M. Y. (2009). Iranian architecture (Islamic Era). Samt.

Koch, E. (2006). The complete Taj Mahal and the riverfront gardens of Agra. Thames \& Hudson.

Maroufi, H. \& Rosina, E. (2017). Cities Hosting Holy Shrines: The Impact of Pilgrimage on Urban Form. ICONARP International Journal of Architecture and Planning, 5(1), 30-44.

Mosavi, Z. (2002). Mogharnas in Architecture. Ketab-e Mah-e Honar, 4546, p. 348.

Nagy, P. T. (2018). Notes on the 14th-century Ya'qubiyya Complex in Tlemcen, Algeria, Periodica Polytechnica Architecture, 49(2), 126-134.

O'Kane, B. (1998). Dome in Iranian Architecture, Iranian Art and Architecture, [Retrieved November 21, 2010, on-line, http://www.caissoas.com/CAIS/Architecture/dome.htm].

Otto-Dorn, K. \& Esin, E. (1967) Al-Qubbah Al-Turkiyyah: An Essay on the Origins of the Architectonic Form of the Islamic Turkish Funerary Monument. Atti del Terzo Congresso di Studi Arabi e Islamici, p. 115.

Otto-Dorn, K. (1979). Figural Stone Reliefs on Seljuk Sacred Architecture in Anatolia. Kunst der Orients XII/1-2., Franz Steiner Verlag.

Önkal, H. (1996). Anadolu Selçuklu Türbeleri [Anatolian Seljuq Shrines]. Atatürk Kültür, Dil ve Tarih Yüksek Kurumu, Atatürk Kültür Merkezi Yayını.

Pope, A. U. (1938). Tents and Pavilions. In A.U. Pope \& P. Ackerman (Eds.), A Survey of Persian Art. (3 ${ }^{\text {rd }}$ vol., pp. 1411-1426). Oxford University Press.

Pope, A. U. (1976). Introducing Persian Architecture. In: Gluck, J., Pope, A. U. \& Ackerman, P. (Eds.) A Survey of Persian Art. Soroush Press. (pp. 5268).

Pope, A. U. (1987). Persian Architecture: The Triumph of Form and Color. (K. Afsar, Trans.). Yasavoli, p. 60.

Rizvi, K. (2011). The Safavid dynastic shrine: Architecture, religion and power in early modern Iran. I.B. Tauris.

Schroeder, E. (1938). Islamic Architecture. F: Seljuq Period. In A.U. Pope \& P. Ackerman (Eds.), A Survey of Persian Art. (8 ${ }^{\text {th }}$ vol, 930-966).

Stierlin, H. (2002). Islamic Art and Architecture: From Isfahan to the Taj Mahal. Thames \& Hudson.

Tolstov, S.P. (1960). Scythians of the Aral Sea and Khorezm. Izdatel'stvo Vostochnoi Literatury. 
Wilson, Ch. (1938). History of Industries. (A. Feriar, Trans.). Yasavoli.

Zaki, M.H. (1941). Iranian Industries after Islam. (M.A. Khalili, Trans.). Tehran, p. 11.

\section{Resume}

Zeynab Nazer is currently a PhD student in history of architecture at BME university, Pál Csonka Doctoral School of Budapest University of Technology and Economics (BME), Budapest, Hungary.

Gergő Máté Kovács has fulfilled his PhD research on the architectural relationship between Hungarian and Ottoman-Turkish architecture and works as Research Fellow at BME, Department of History of Architecture and Monument Preservation. Peter Rabb is a visiting lecturer at the Faculty of Architecture of Ylldiz University of Technology, Istanbul and the Faculty of Fine Art, Design and Architecture of MEDIPOL University, Istanbul. 